\title{
(Digital) Activism at the Interstices: Anarchist and Self- Organizing Movements in Greece
}

\author{
Eugenia Siapera* and Michael Theodosiadis** \\ *Dublin City University, eugenia.siapera@dcu.ie \\ ${ }^{* *}$ Goldsmith’s, University of London, mtheo001@gold.ac.uk
}

\begin{abstract}
The paper traces the history and evolution of the anarchist and self-organising movements in Greece, paying attention to their communicative practices and their implications for political praxis. After years of repression, and following the hegemony of the social democratic Pasok, and subsequently Syriza, the movements are currently coming to their own. Beginning with a brief history of the movements and more broadly of the left in Greece, the paper focuses on the current moment, determined by three events: the revolt of 2008, the movement of the squares in 2011, and the rise and U-turn of Syriza in 2015. Examining the critiques, discourses and communicative practices of the antagonistic movement as a whole, the paper argues that these tendencies can make up an alternative path to organizing beyond populist hegemony. The antagonistic movement tried to eschew the problems associated with the so-called folk politics, by paying attention to the growth of popular alternatives through combining affect and experience, new learning and action, ultimately contributing to fundamental shifts in political subjectivities.
\end{abstract}

Keywords: Greece, Syriza, populism, media, digital media, social media, anarchism

\section{Introduction}

Greece has been experiencing crisis and contention since the December 2008 events, which played a pivotal role in the emergence of the 2011 Syntagma Square movement (Douzinas 2013, 143) and the rise to power of the populist left-wing party Syriza to power. This, however, only tells part of the story. At the interstices created by state repression and state withdrawal, by the hegemonic project of Syriza and the escalation of reactionary populism, Greece saw the emergence of anarchist and selforganizing initiatives that defy any straightforward categorization. What is the role and impact of such movements for the future of political activism? How do these movements appropriate and socialize digital media? This paper addresses these questions, examining their communicative and political practices and discourses. It also brings into discussion the project of populist hegemony, conceptually developed by Laclau (2007) (a project utilized by Syriza), and includes a critical examination of the so-called folk politics, which, as Srnicek and Williams (2015) argue, instead of proposing a coherent organizing strategy or purposeful political action, relies solely on affect and contagion. The discussion provides an insight into the actual political world created by such movements and their use of digital media. We argue that these movements - to which we refer collectively as the antagonistic movement, and which includes anarchists, libertarian communists, radical socialists and autonomists - rely on communication strategies that retain a link to the past, creating bonds and connecting with others in the present, imagining and constructing a common future. This allows them to establish a common political world inhabited by strong and con- 
sistent political identities. In this way, they differ from other movements in Greece and elsewhere that use communication as a form of propagation and persuasion, and which rely on loose connections and vague ideologies.

\section{Background and Genealogy}

This section investigates the political discourses of the Left as well as of the selforganization movements in Greece, from a genealogical perspective, examining, also, their articulations with media of communication. It aims to understand morals and modes of being in relation with succeeding events and notions that symmetrically appear on different stages of the historical process (Foucault 1977, 152). Two arguments emerge from this perspective: firstly, that the media are not cut off from their historical and political environment, and secondly, that it is expected that variations in political 'modes of being' will be associated with variations in media 'modes of being'. These variations can operate both genealogically but also in a contemporaneous, synchronic manner. In this section we identify three milestones of Greece's modern history, which shaped the formation of the current left-wing discourses. These are: the political climate after the end of the First World War; the German Occupation and the Civil-War era; and the period of Metapolitefsi, a term "used to describe the historical period of modern Greek history that follows the end of the colonels' dictatorship (1974)" (Vradis and Dalakoglou 2011, 339).

The emergence of socialist movements in Greece can be traced back to in the beginning of the twentieth century. Some of the most notable cases include: the clashes between workers and employers in the Lavrio mines (1906) and Serifos (1916), as reported by Kordatos (Kopסátos [1956, 184-5]). But the most significant developments took place after the end of the First World War, with the further spread of socialist ideas across the country.

The rise of the dictator loannis Metaxas to power in 1936 resulted in brutal suppression of dissent and trade-unionism (Mazower 2001, 103). The regime was characterized by intense media censorship, targeting mainly socialist newspapers, such as Rizospastis (the Radical) the newspaper of the Greek Communist Party (KKE), and publications such as Class Struggle and New Society, both Trotskyist and socialist variants. Metaxas imprisoned hundreds of thousands of socialists and tradeunionists. Repression and persecution of communists, anarchists and socialists continued during and after the German occupation. In response to the German invasion, in September 1941, the KKE in collaboration with small left-wing parties, established the National Liberation Front (EAM), which quickly became the largest movement of the Greek National Resistance against the Axis occupation (Mazower 2001, 96: Kouooupńs 2014, 58 [Kousouris 2014, 58]). EAM's attempts had a strong radicalising influence on the Greek people, through public speeches and propaganda, distributed mainly by Rizospastis (Mazower 2001, 288), and direct action: while food scarcity claimed hundreds of thousands of lives, many EAM/ELAS fighters (the andartes) managed to supply food to starving villages. EAM's discourses and actions influenced social and political struggles and are still influential; slogans used by EAM/ELAS during the Nazi occupation and the Greek civil war have recently resurfaced, along with photographs circulating as memes, while references to battles fought by EAM have re-entered the political vocabulary some seventy years later.

The appointment of Rallis as the third collaborationist Prime Minister of Greece in April 1943 inaugurated the official start of the 'war against communism' (Mazower 2001, 323). Rallis gathered together all 'disciplined citizens' "to restore order at home" (Ibid., 322). Reactionary anti-communist forces, the so-called Security Battal- 
ions (SB), were formed, receiving financial assistance by from the Germans. Their discourse was associated with the far-right call to 'save Greece from the Bolsheviks', classifying the forces of EAM as the enemies of Greece. EAM and the KKE, on the other hand, were criticised by many Trotskyists, such as Castoriadis and Stinas (Curtis 1998, viii), who believed that the KKE was using Stalinist repressive methods against anyone who challenged its ideological hegemony. Its communicative and media strategy, including communications between its members and between the party and the broader public, was one of total top down control of ideas and news. It was embodied by Rizospastis as the 'organ' of the central committee of the party and by the numerous 'instructors', or party apparatchiks responsible for the recruitment, ideological guidance, and coordination of party members.

After the liberation of Greece in 1944, major clashes had begun in Athens between EAM guerrillas and the forces of the British army and their Greek collaborators. The clashes of December 1944 ended with the defeat of EAM/ELAS, which was forced to hand over their weapons to the authorities. The andartes who refused to capitulate were hunted down by government troops (Mazower 2001, 373). A right-wing backlash followed the defeat of EAM and as a result bands of resistance fighters reformed, setting up the Democratic Army of Greece (DSE), which was "fundamentally controlled by KKE" (Vradis and Dalakoglou 2011, 338). DSE, however, was totally defeated by the British army. Thousands of its members were incarcerated, faced execution, or fled to Eastern Europe (Mazower 2001, 376). Meanwhile, "hundreds of men who had fought in the Security Battalions alongside the Germans found their way without any difficulty into the postwar National Guard" (Ibid., 334). This period established the ultra-repressive post-civil war state, marked by constant liquidation of communists and left-wing supporters and tough sentencing of dissidents in harsh forced labour camps in penal islands (Voglis 2000, 73-90). Operating in conditions of illegality, both during the German occupation and effectively until 1974, the Communist Party controlled almost all the leftist media, and the leftist ideological and political landscape, notwithstanding the great influence of thinkers such as Castoriadis, Stinas, Poulantzas, and Tamtakos et al.

During the years of repression, communications between political movements and the people were limited to face-to-face discussions, although a series of, for the most part, illegal newspaper and smaller publications circulated in the underground, and during the 1967-1974 junta, publications from Greek exiles in Europe (Radiobubble 2013). The Greek National Archiving Centre lists 40 illegal titles printed mostly in Athens, compared to the five legal print media that circulated during the German occupation. In 1944 there is an explosion of left media: EAM published 116 titles across Greece while KKE published another 93 (Ibid.). However, these titles were all banned following the defeat of DSE. The period of 1955-1963 was characterized by unprecedented repression, with the members of the Secret Police (KYP) were proportionally more than the members of the German Stasi, if we take population size into account (Radiobubble 2013). While the repression eased somewhat in the years 1963-1967, the period of persecutions ended with the collapse of the anti-communist dictatorship of 1967 in 1974 (Theodosiadis 2015). The fall of the dictatorship is attributed to the student revolt at the Polytechnic University of Athens in November 1973. According to Trocchi 2011, 303) the Polytechnic uprising "reduced the popular tolerance of the military junta, which was one of the factors that eventually led to its collapse in 1974". This revolt is considered as a milestone for the antagonistic movement in the country (Kaplanis 2011, 227). It is looked at as "an ultimate archetype of resistance" (Ibid., 2) that has shaped the consensus of Metapolitefsi (political changeover), signalling the 
end of the right-wing hegemony, and the termination of institutional discrimination,

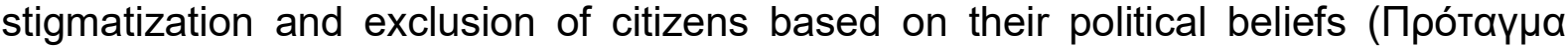
2013, 48 [Protagma 2013, 48]). This attitude of the victimization of the resisting and heroic Greek left is also reflected in the left-wing anti-austerity movements and especially in pre-2015 Syriza's official discourse. In this, Syriza merely took over and continued the discourses associated with Pasok - the 'Panhellenic Socialist Movement' led by Andreas Papandreou.

Under the populist/socialist reforms of Pasok's first government in 1981 things changed drastically in Greece (Kornetis 2013, 303). Civil marriages were introduced, whilst measures that restricted freedom of expression were repealed, in conjunction with the legalization of left-wing parties and the recognition of EAM/ELAS National Resistance. The new consensus contributed to the rapid folklorization of the student struggle and the institutionalization of anti-junta activism (Ibid., 301). As a result, a strong anti-rightist attitude in the public flourished, although reactionary discourses and ideas survived. Supporters of the post-Civil War anti-communist (and pro-Junta) consensus had to either hide their extremist profile by compromising with the most conservative wing of the centre-right party New Democracy (Theodosiadis 2015) or associate themselves with the discourses of many Christian fundamentalist Orthodox pastors, who became the pioneers of parochial isolationism and national-populism in Greece (Stavrakakis 2005, 227). After 2005, they gradually emerged from the fringes through the rhetoric of the right-wing populist party LAOS and later Golden Dawn. At the same time, during the Metapolifsi consensus, new tendencies and discourses emerged, including radical leftism, anarchism and feminism (Kornetis 2013, 301302).

The first re-appearance of the antagonistic movement took place during the Polytechnic uprising. During the 1980s and 1990s anarchism begun to spread among the young Greeks, primarily through alternative (collectively owned) media, creating an alternative discourse, beyond the statist ideology of left parties, neoliberalism or reactionary populism, as well as beyond liberal democracy. Punk subcultures and countercultural trends, emerged especially around the area the Exarcheia ${ }^{1}$ district of Athens. In a way such currents are the continuation of countercultural movements (like the yieyiedes and tediboydes - hippies and 'teddy boys') that initially emerged during the 1960s (Kornetis 2013; Ovenden 2015).

The dual repression, coming from the Communist Party and from the state, and which went on until the 1970s, is a significant explanatory factor for the reluctance of alternative political groups to follow party political structures and organizational methods. It was not until an internal division in the party in February 1968 that led to the creation of KKE 'Interior', a euro-communist variant, that the KKE began losing its stronghold (Ovenden 2015, 21). In the years of Metapolitefsi, the media and ideological-political landscape was characterized by the populist hegemony of Pasok, its appeal to a faux third-worldist and eurosceptic rhetoric, even as it upheld and inflated the clientalist relations established by its right-wing competitors. Pasok established a firm control of the media, through subsidizing publications via state advertising and making preferential deals with media owners. This was even more pronounced in the case of commercial broadcasting, established in 1989, in a confused, partially deregulated landscape which once again reinforced clientalism (Hallin and Papatha-


country's post-dictatorial era (1974-present) have been centred" (Vradis and Dalakoglou 2011, 77-78). 
nassopoulos, 2002). Papathanassopoulos (2001) argues that commercialisation in a completely unregulated media landscape gave rise to a kind of journalism that was liable to both political control by the state and to commercial pressures. On the other hand, however, throughout the 1990s, there was an explosion of alternative publications, for example the publishers 'Free Press' (Eleutheros Typos), but mostly through brochures, some magazines, some weekly newspapers, but most of these were small scale and ephemeral (Metropolitan Sirens, 2011).

The leftist, anarchist and libertarian movements in Greece have been involved in most large protests, and especially those against globalization. In June 2003, there were large- scale protests in Thessaloniki against the European Union summit, partially organized by the network Antiauthoritarian Movement (Antiexousiastiki Kinisi), which had also participated in major anti-globalization protests for example, in Rostock in Germany in 2007. The main medium of the movement during this period was indisputably Indymedia Athens, while other media included digital versions of print publications and a series of blogs. Digital archives, such as for example, eutopia.gr, show a vibrant alternative-anarchist media landscape, including print publications such as Nea Selene, The Anarchist, Counter-Information Bulletin, the Forbidden Press, Ideologio and more. The famous anarchist magazine Apatris (Stateless), one of the most notable Greek anarchist papers, recounts plenty of magazines and newspapers, such as Enantia (Against), Alfa, the Gilotina (Guillotine) as well as Mavri Simaia (Black Flag), Resalto, the anarcho-syndicalist Rocinante, and Drasi (Action) ${ }^{2}$. This vibrant landscape remains to this day, with some of these publications appearing still in print and digital forms, but a closer analysis reveals several points of departure. While in the early 2000s anarchist and alternative movements were marginal, by the mid-2010s their position in the Greek political landscape had changed dramatically. The pivotal moment was the December 2008 revolt.

\section{The Present Moment: 2008 and Beyond}

It is our contention that the events since 2008 cannot be understood outside the history of the movement discussed above. This history and what followed the events of 2008 show that it is impossible for this movement to ally itself to any political party of the left, including KKE and Syriza, even if briefly Syriza sought to recruit and subsume the movement under its hegemony. The turn of events following the murder of Alexandros Grigoropoulos on December 6, 2008 were both in direct continuity with Greece's anti-authoritarian past and signalled a break and rupture from it. The December revolt was not planned or led by any party (Douzinas 2013, 140). Syriza, nonetheless, was the only parliamentary group expressing "clear sympathy for the youth in revolt" (Ovenden 2015, 52) while all other parties (as well as the media) condemned the events, while MPs of the then ruling party, New Democracy, threatened to impose military law in the streets of Athens. The media and the mainstream political forces made no effort to understand the meaning of the events, focusing exclusively on violence and looting. Echoing the events during the Polytechnic uprising, self-organization, togetherness and friendship replaced terror and mistrust, and a public realm began to emerge; "neighbourhood assemblies along with the occupations of schools, universities, municipal offices and theatres taking place and a wide-

2 For a brief history and discussion of anarchist publications in Greece see http://eagainst.com/articles/a-brief-historic-review-of-anarchist-newspapers-ingreecel 
spread rejection of apathy, cynicism, the tyranny of financial uncertainty and political indifference" (Theodosiadis 2013). The December revolt was, according to Kouki $(2011,170)$ an "experience of socialisation". In the words of those who participated in the events, "by living in an egalitarian moment, we changed in one night the terms of inclusion and exclusion. We transformed from invisible solitary figures rambling around in our urban misery into political subjects who managed to challenge, not the solutions that had to be applied to a situation, but the situation itself" (Kouki 2011, 169). Hence, the December revolt, although it was not exclusively an anarchist event, was partially inspired by anarchist ideals. It shaped a discourse that set the foundations for the emergence of the movement of the squares in Greece and Spain (Douzinas 2013, 147).

The revolt further highlighted the role played by the new media and more specifically Indymedia Athens, which shortly after the December events became the main channel that disseminated anarchist ideas to the Greek public. During the revolt, Indymedia Athens transmitted news through the eyes of activists and demonstrators (Metropolitan Sirens 2011, 139), and it reached tens of thousands visitors per day (Vradis and Dalakoglou 2011, 18), while up to 2011 it was among the ten most popular websites in the country (Metropolitan Sirens 2011, 139). At the same time, the anarchist space grew rapidly, and squats, self-organized parks and social centres emerged almost in every neighbourhood (Filippidis 2011, 54). In many ways, therefore, the 2008 revolt prefigured the movements that followed.

The years that followed 2008 were extremely traumatic for the Greek social body, characterized by political meltdown, following the financial crisis. Two further events were significant in understanding the present moment in Greece. The first was the Aganaktismenoi or movement of the squares in 2011 and the second the electoral win of Syriza in 2015. The former was characterized by a popularization and broadening of a protest culture, wide inclusivity and popularity. While the movement of the squares folded in the summer of 2011, Syriza managed to capitalize on the generalized discontent, to successfully adopt and adapt the rhetoric of the squares and the left tradition in Greek politics. Syriza succeeded in getting elected in January 2015, forming a coalition government with a right-wing, national-populist party, the Independent Greeks (ANEL).

\subsection{The Squares and the Rise and Fall of Syriza}

The protest media landscape at this stage has been usefully discussed in a series of studies that position it within broader and more global developments, revolving around the rise in the power of social media, the Arab Spring, the Occupy movements in Europe and the US, and the 15M movement in Spain. Researchers here have focused on the use of social media in constructing an identity and collective voice for the movement (Kavada 2015), on the emergence of organic leaders or hubs from within the movements (Gerbaudo 2012), on the varied and innovative media practices (Costanza-Chock 2012), on the role of the hackers and information technology experts (Postill 2014) and more broadly on the shifting paradigm of protest politics (Bennett and Segerberg 2013). From a critical perspective, Fuchs (2014) has outlined the role of social media corporations, censorship and surveillance while Dean (2012), though recognizing the value of these movements, poses broader questions of capitalizing on the gains without becoming part of the system and moving towards a more stable form of organization such as a political party.

With respect to the Greek movement of the squares, Theocharis $(2015,185)$ identifies four points of departure from previous protests: firstly, while previous protests 
were organized and coordinated by trade unions and political parties, the movement of the squares self-organized without any support or guidance from such actors - although it has to be said that some became involved at some stage, notably Syriza and groups allied to Syriza. Theocharis, however, is not taking into account the ongoing actions of the antagonistic movement which always operates at the interstices and had always turned away from political parties and trade unions. Secondly, Theocharis argues, through social media, the movements succeeded in establishing ties with similar protest movements in Greece and abroad, most notably with the $15 \mathrm{M}$ movement in Spain. As we have seen however, in the case of Genoa, Rostock and Thessaloniki, the antagonistic movement had already built such international solidarity ties. Thirdly, these movements succeeded in mobilizing people who were not involved in any protests before, while finally, Theocharis (2015) argues that the loosely connected networks formed during this time (2011) were sustained beyond and were tied to solidarity initiatives months and years after the movements were evicted from the squares. Following Theocharis, we would argue that the novelty lies in the opening up of the protest space, which became more inclusive of a variety of people, beyond the confines of Exarcheia, as well as in the maintenance of the bonds created in the squares, which fed into solidarity initiatives. This happened in part because social media allowed for the continuous connection of people, but as Rakopoulos (2014) has shown, bonds of trust require (also) face-to-face contact.

In the elections that followed the movement of the squares in Greece in 2012, it became clear that the political winner was Syriza, whose rhetoric was very similar to the rhetoric in the squares, speaking of anti-austerity, an end to corruption, 'real democracy', and social justice (Prentoulis and Thomassen 2014, 213). Stavrakakis and Katsambekis (2014), drawing on Laclau (2007), have argued that Syriza's success can be attributed to the way in which it managed to concatenate demands in chains of equivalence around the notion of the people and to create an internal frontier between 'them' and 'us', those in power and the underdogs. But it is also clear that these equivalences and the internal polarization were already part of the Greek public discourse and they were apparent in the movement of the squares, and also long before, in the genealogy of the Greek left discussed above. Syriza can then be seen as successful only insofar that it managed to present itself as an empty signifier, and to distance itself from Pasok, which was very closely associated with the period of Metapolitefsi. In these terms, the electoral victory of Syriza in 2015 shows that it successfully subsumed the popular demands articulated not only in the movement of squares but throughout the history of the Greek left. It was voted in with the mandate to restore social justice and avenge those who had died for it. Tsipras's highly symbolic gesture to lay a wreath in the Kaisariani monument, where the Nazis had executed 200 communists in 1944 was a testament to that, alongside the (now ironic) slogan 'left for the first time'.

However, events since showed that the popular demands for social justice were frustrated in the long months of the supposed negotiations between the Syriza coalition government and the institutions representing the creditors (the infamous 'Troika', the EC, ECB and IMF) - though some commentators argue that Syriza had already changed in the months following the 2012 elections when it became obvious that they had the potential to govern (Ovenden, 2015; Sheehan, in press). The turning point for Syriza was the 5 July 2015 referendum (Ovenden 2015, 157). Although 62\% voted against any further bailout agreements with the creditors, Tsipras performed a U-turn and announced an agreement to sign a third bailout programme with even more stringent terms a week after the referendum. Despite this, Syriza was elected 
once again in September 2015, on the platform of the so-called parallel programme, a 'social justice' programme that was supposedly going to be implemented in parallel with the 'reforms' demanded by the creditors. However, the great social force and dynamism that accompanied Syriza was lost, along with a good chunk of its members and supporters. In May 2016, the Syriza government voted in favour of another bailout, the worst yet, which effectively privatizes everything and moreover hands over the control of the 'reforms' (i.e. privatizations) to the creditors.

Moving from Syriza's hegemonic practices to the practices of those who operated outside this hegemony whilst still subscribing to social justice agendas and to ideas of freedom, we identify an altogether different political modus operandi. Although these groups were involved in the 2008 revolt and in a number of protests, they voiced significant criticisms towards the movement of the squares even as they participated in it. During and after the movement of the squares, we can observe a clear split between those who followed Syriza and the political party line pursuing hegemony and those who self-organized and who ran self-management and social solidarity initiatives. This is not to say that these were immediately positioned against Syriza but that they operated in parallel or beside Syriza, at least for the period before the summer of 2015.

\subsection{The Squares and the Critiques}

This split can be observed already in the days of the movement of the squares, where anarchist and libertarian groups were voicing their criticisms and objections: four main and inter-related points that were raised included firstly, the dominant role of affect in the mobilizations; secondly, the demand for the immediate implementation of direct democracy without paying attention to the actual subjectivities and practices that such a political regime requires; thirdly, the underlying demand was understood as a (re)turn to social democracy or to some form of benign capitalism, pointing, fourthly, to the uncritical openness to all, without considering the diverse social positions and ideologies they represented ${ }^{3}$.

As we shall see later, the criticisms of these groups concerning the affective dimension of the movement of the squares and its communicative practices reflect in some ways the criticisms levelled by Srnicek and Williams (2015) against what they call folk politics. The problem is not that affect is expressed or that it forms the impetus for mobilizations, but that it is pegged against more rational and sober analyses of the situation, against strategic planning and effective organization. Ultimately, the problem with affect according to this line of thought is that it opens itself to easy solutions expressed by 'messianic' political parties that will somehow parachute in and make everything good again. In these critiques, affective expressions are accepted but they have to be accompanied by grounded reflection as to what caused them and what may be the way forward.

For these critics therefore, the problem of affect as the motivator of action is that it needs to be articulated politically. The inability of fusing affect with critical and politico-strategic thinking allowed on the one hand its use by reactionary elements that

${ }^{3}$ The discussion here relies on an analysis of the discourses of a number of blogs and websites of the field, as published at the time. See for example, eAgainst, 2011, Criticisms of the Aganaktismenoi movement, http://eagainst.com/articles/\%CE/; Mila $\mathrm{Re}$, the Indignants of Mordor, May 2015; the blog of the group Libertarian Communists, http://eleftheriakoi.blogspot.ie) 
existed in the squares. On the other hand, affect was associated with the formulation of 'naïve demands' for direct democracy, that overlooked both the actual social labour that this involves and its incompatibility with the present capitalist system. For some groups, the people in the squares merely play-acted the procedures of direct democracy, such as going to a podium to speak, but without an overall frame that would allow for a fruitful discussion eventually leading to a political decision. This watered down version of direct democracy was attributed to the lack of a developed political subjectivity and know-how: an article in the blog AvantGarde shows the contradictions involved, pointing to the number of people who went to work on a day of a general strike only to join the squares and complain about the system in the evening. ${ }^{4}$

The lack of a systematic political critique alongside affect and biopolitical experiences was in turn associated to superficial and naïve demands for a "capitalism with a human face' or some form of a return to the social democracy of early Pasok, which represented a historical compromise between the demands of labour and those of capital. But such demands were seen as impossible and contradictory to demands for direct democracy, and were exposed as such ${ }^{5}$. The ideas for a democratic reform of society that circulated in the squares and that were subsequently mobilized in Syriza's rhetoric were already received very critically by those who were seeing in these the promise of a generalised revolt appeased and domesticated by political parties. ${ }^{6}$

In part, the movement of the squares brought this about through their insistence on the openness and inclusivity of the movement. By refusing to address the question of 'them' and 'us' within the squares they opened up to elements such as the fascists and nationalists, as well as those committed to a reformist view of representative democracy. "There was no confrontational philosophy since half [of those in the squares] wanted to offer a rose to the riot police that had drowned them with tear gas and had battered protesters [...] They were not interested in changing the system, they were not interested in self-organising, they just wanted to be in the squares. This is not a movement, it's 'hippyism'" (Re 2015).

A parallel approach here focused on different parameters mainly reflecting the ideas of Cornelius Castoriadis, Hannah Arendt and Jean-Claude Michea - expressed through the website Eagainst.com and print/online magazines such as Babylonia and Protagma. This line of thought was frustrated with the isolationism of some of the anarchist elements. They saw the reluctance of many anarchists to become engaged with the people in the squares as representing a form of isolationism, revealing a tendency of some anarchists to become trapped within an ideological microcosm, instead of influencing movements and popular initiatives (Theodosiadis 2014) ${ }^{7}$. Additionally, this strand of thought claims that the sectarian Leninist left is unable to understand the spontaneity of many popular uprisings ${ }^{8}$, whilst some appear trapped within the logic of Stalinism. In the same line, Protagma condemns not only the es-

${ }^{4}$ AvantGarde, 2011, 16/6, Where were the Indignant yesterday?

(https://avantgarde2009.wordpress.com/2011/06//)

${ }^{5}$ See: http://eleftheriakoi.blogspot.ie/2011/06/blog-post 1067.html and eAgainst, http://eagainst.com/articles/\%CE/

${ }^{6}$ See: http://eleftheriakoi.blogspot.ie/search?updated-max=2011-06-27T22:34:0007:00\&max-results $=5 \&$ start $=5 \&$ by-date $=$ false

${ }^{7}$ See: http://www.nostimonimar.gr/\%CE\%

${ }^{8}$ See: http://eagainst.com/articles/all-power-to-the-assemblies/ 
capist attitude of the anarchists, but also attacks the tactics of many left-wing orators, politicians and party followers to hijack the squares ${ }^{9}$.

These critiques show the tensions and contradictions between and within the squares, Syriza and those following the genealogy of anarchist, libertarian, communist (non-KKE) and self-organizational/autonomist thought. The discussion also reveals inner splits and contradictions within the libertarian spaces themselves, primarily between anarcho-communists and supporters of direct democracy/autonomy. However, the main split is between mainstream left political parties such as Syriza and KKE and the antagonistic movement in its entirety, notwithstanding the tensions between its constituent parts. Taking these into account, the communication strategies and practices of the antagonistic movement are different, corresponding to a different communicational 'mode of being'. These communicational approaches follow through the criticisms elaborated above seeking to build a political movement that is able to address the challenges of the present.

\section{Communication Strategies}

We use the term strategy to point to the ultimate political goals of the communications of the antagonistic movement; we are interested in the ways in which these strategies contribute to achieving the movement's political goals of freedom, justice and autonomy. The analysis therefore asks: what is it that the antagonistic movement communicates and how? What are the political implications that this has? We address these through looking at both the contents and the means by which these contents were communicated. The analysis showed the following: the communications of the antagonistic movement have a pragmatic orientation to the needs of the here and now; communication is understood as way of strengthening the bonds and building solidarity between various groups in Greece and abroad, connecting them laterally; communication is construed as critique and discussion beyond dogmatic ideological approaches and attempts to persuade, and as a contribution towards the strengthening of critical analysis through the free publication and translation of important theoretical works, attention to archiving, and in depth critical articles and analyses.

Overall, our analysis relied on a close examination of the digital presence of the antagonistic movement. This includes blogs, social media pages and websites of groups, collectives, and individual participants. Specifically, we have looked at the blogs, Facebook pages and Twitter feeds of groups such as the anarcho-syndicalist Rocinante, Rising Galaxy, Anarchiki Bibliothiki (Anarchist Library), Mpalothia, the Anti-Authoritarian Movement, the various interconnected Networks for Social Solidarity (for example, Network for Social Solidarity, Solidarity for All, Initiative for Solidarity to Vio.Me, Social Solidarity Clinic and others), Anarchiki Ichoripansi (Anarchist Sound Pollution), Dromografos, Kollect, the many pages of the Greek AntiFa Movement, No Borders and the refugee solidarity initiatives, for example, City Plaza and Solidarity2Refugees, Omnia TV, Protagma, Babylonia Magazine and many others, as well as individual accounts of activists on Twitter and Facebook. The common parameter here is that all these belong to the antagonistic movement and would describe themselves politically as anarchist, libertarian communist, radical socialist, and autonomist.

In terms of the material aspects of communication, we should note that, following several attempts to shut down Indymedia Athens, and commensurable with the cri-

\footnotetext{
${ }^{9}$ See https://protagma.wordpress.com/2011/06/10/\%CE\%
} 
tiques against corporate control of the internet and social media, part of the movement, and specifically the Cybrigade collective, has set up and runs its own server, espiv.net which offers a number of digital services ${ }^{10}$. The digital part of the movement is therefore not limited to corporate social media but exists across the web, and includes live ongoing blogs, accounts and pages, online radio, online counterparts of print magazines, as well as inactive blogs and sites, which function as archives.

With respect to the contents we see a clear orientation towards pressing needs in the here and now. They call for ongoing and immediate action, for example, participating in street protests, supporting arrested protesters, but also gathering food and supplies for refugees and others in need. In particular, the refugee crisis galvanised the movement into action, firstly because of the immediate needs that refugees have, in terms of food and shelter, and secondly, because of the threat of attacks by fascists. Calls for immediate action pay attention to the need for survival in the present but also require the institution and organization of structures that can address such needs. In the first instance this involves the setup of communicational structures, mainly through social media pages and accounts that can quickly reach a significant number of people in the vicinity and beyond.

Secondly, groups communicate the actions, requests and news of groups elsewhere in Greece or abroad. Articles that offer details about actions undertaken, future plans and projections for future needs, news about events, strikes, protests and news about self-organizing and self-governing initiatives elsewhere are posted, shared and commented upon in social media pages and in blogs.

Thirdly, communication is concerned with the in-depth analysis and understanding of the world. This is a crucial element and it is carried out primarily in blogs, and reposted, publicized and promoted through social media accounts. Through translations, interviews, articles and analyses, groups that belong to the antiauthoritarian/self-organizing tradition undertake the sharpening, clarification and discussion of their political positions. Torrent sites such as Black Tracker (http://www.black-tracker.gr/), communal translation sites such as Rebel.gr and Contra-Info, archives and online libraries such as Anarcheio (anarxeio.gr) and Eutopia (eutopia.gr), offer a great variety of important theoretical texts translated in Greek, back archives of anarchist and autonomist publications from Greece, as well as videos and music. Moreover, online (and print) magazines such as Babylonia (http://www.babylonia.gr/), Respublica (http://www.respublica.gr/) (the successor to Eagainst), Provo (provo.gr) and Protagma (https://protagma.wordpress.com/) are involved in the production of articles and commentary about the world, Greece, selforganization and autonomy.

Though these blogs and social media pages are in principle open, they are very clear in terms of their publication policies. One of the clearer statements comes from one of Mpalothia's social media accounts, that of a Facebook group:

"The group Mpalothia-Counterinformation is concerned exclusively with topics of counter-information primarily for the anarchist/anti-authoritarian movement, the antifascist struggle and for any form of struggle against any state and any authoritarian construct. [...] Any posts that are

${ }^{10}$ In a significant linkage between the past and the present, the servers of Indymedia Athens and Espiv are hosted at the Polytechnic University and Panteion University respectively. 
considered irrelevant or supportive of the parliamentary and bourgeois political system will be deleted. The same goes for any posts linking to regime or for profit media or sites"11.

This statement is typical in drawing clear boundaries as to who can be part of this group and under what conditions. In doing so, they seek to retain a clear identity and prevent co-optation or exploitation. In this manner, the movement is open but only to a select group of people. Their 'them' and 'us' is therefore posited in clear rather than ambiguous terms preventing any misinterpretation, wilful or not.

Drawing out the political implications of these communications, we note that notwithstanding the conditions placed, the communications of these groups are addressed to broader publics and are not esoteric, obscure, or exclusionary. We understand these as an attempt to reach out to publics but outside typical populist frames that fudge ideological issues by references to a generic people. At the same time, we note that communications of the antagonistic movement operate beyond attempts to scale and persuade. For example, there is very little use of symbols or affective signs. Indeed, while symbols are used (for example, the colours red and black, the sign of anarchy etc.) these are mobilized as affirmations of identity in cover and profile photos, rather than as memes to be shared. Evidently, the antagonistic movement's communications do not look for shares or likes nor are they interested in persuasion through propaganda; rather, they seek to contribute to shifts in consciousness and, as they put it, to 'enlighten'12 in the literal sense: to throw light into a situation continuously obscured and distorted by the mainstream media and other authoritarian institutions. The movement itself understand their communications as counterinformation: this refers to the production and circulation of information outside of dominant institutions and the commodified for-profit economy, while also being antagonistic towards the dominant ideology. Counter-information is seen as having a dual role: to diffuse the views of those in the movements and to actively undermine the monopoly in the production and circulation of ideas and meanings (Katalipsi ESIEA, 2013).

In short, taken together these communicative strategies sustain, strengthen and support the antagonistic movement in Greece. They provide continuity with the past, bonding with others and organising in the present, while they also enact the future through their involvement in the solidarity economy and in various occupations/squats and refugee support initiatives. In the next section we will argue that these aspects and the broader discussion of counter-information explicit in these groups has the important political function of socializing the anarchist, libertarian, radical socialist and autonomist movements in the sense of returning and repositioning them from the margins to the centre of society, building local and global solidarities while sharpening and refining critical skills for political analysis thereby restructuring political subjectivities.

\footnotetext{
${ }^{11}$ See https://www.facebook.com/groups/796512193720081/. Very similar policies are found in other sites, for example in the Contra-Info network (https://encontrainfo.espiv.net/terms-of-publication/), Mia epochi stin kolasi (https://www.facebook.com/notes/\%CE) and others.

${ }^{12}$ See for example the interview of the Exarcheia publisher Giorgos Garmpis in 2013: http://eagainst.com/articles/garmis/
} 


\section{Connecting the Threads}

Following the above discussion on the communication strategies of the antagonistic movement, we note a significant departure from the genealogy of leftist movements in Greece. Looking at the discourses or the substantive parts of their communications, these are outward looking and guided by three pivots: capitalist crisis, people in need (refugees and impoverished Greeks), and self-organization and autonomy. Questions of fighting state power remain important but have become secondary because of the pressing needs to understand and deal with the present situation and because of the dramatic retreat of the state in recent years. Nevertheless, critiques and actions against the state repressive apparatuses such as the police and prisons remain important. Discourses that follow and build upon the gains, failures and critiques of the movement of the squares and the fall of Syriza, point to the reformulation and reconstitution of the antagonistic movement as an important political actor. In these terms, we can observe an important shift and movement from the margins to the centre, because the antagonistic movement has made important contributions to the need to understand, survive and move beyond the crisis and because of this they have found resonance in Greek society at the present historical juncture. This section will begin with a brief discussion of the collective identity, publics, and communications of the movement. Building on this, it will mark their departure from current political thought as expressed on the one hand in the Laclauian theories of populist hegemony and on the other in the critique of folk politics expressed in Srnicek and Williams (2015).

A question that has been at the forefront of recent discussions of current protests and activism is that of the movements' identity (Bennett and Segerberg 2012; Gerbaudo and Treré 2015). Bennett and Segerberg (2012) posit that in instances of connective action where personalized networks and weak connections are favoured over stronger ties and ideological affinities, a collective identity is no longer necessary. This is clearly not the case in the kinds of groups examined here, which have a strong collective identity and sense of who they are and what they are about. At the same time, we can observe both continuity and rupture. These can be seen as the result of historical and material changes, including those of the crisis and the increasing availability of the internet and social media. We traced the antagonistic movement from the long years of state repression and persecution through the marginalisation by the popular hegemony of Pasok. However, it was in the years following the 2008 revolt and the subsequent deepening and intensifying crisis, and during and after the movement of the squares that the groups that comprise the movement began to shift their attention from police fights and rioting to consistent social action across urban centres and neighbourhoods beyond Exarcheia. At the same time, the position of Greece at the crossroads of two major and related capitalist crises, the debt crisis and the refugee/migration crisis, has reoriented the movement and its purpose from a narrow and localized focus towards a more global outlook. The movement acknowledges, and refers to, its historical antecedents which had a strong anarchosyndicalist component, but moves beyond the local and national focus of the previous era. Instead of channelling all energies to strikes and fighting the police, their political energies are invested in building up and maintaining self-managed social spaces and contributing to solidarity networks across Greece. In all this we can observe the contribution of digital communications. Translations and interviews help build digital global solidarities and connect similar movements across the world in a lateral manner, spreading experiences and know-how; this not contagion but purposeful dissemination of knowledge that underpins and guides action. Online maps 
and links connect initiatives in various cities in Greece and coordinate actions. Archives of books, brochures and digitised old magazines retain links to the historical past of the movement. The ideological and theoretical texts alongside position articles and political analyses, provide a strong backdrop that justifies and explains actions, while crucially they allow the field to be ideologically coherent and systematic.

Because of their strong political collective identity, the public to whom they are addressed is very specific: in the first instance, it includes those who share the same class background and this means members of the working class, those in low-paid and precarious positions, the unemployed, immigrants and refugees ${ }^{13}$. Secondly, everyone else provided that they agree with their political ideas. Explicitly excluded are those who are seen as upholding bourgeois and petty bourgeois ideology and who promote for-profit relations. In a movement that underwent so many years of persecution and repression, secrecy and barriers to membership have served to protect them, but in today's environment barriers and controls are further imposed to retain a sense of the movement's identity and prevent co-optation. Moreover, the emphasis on the class credentials and the deep divides between classes point to an explicit class positioning rather than an address to a general public or 'the people'. Blogs such as Prolenet (prolenet.gr) or accounts such as @misos_taksiko ('class hatred') are very clear in terms of where they stand and who they are addressing. Although this has a cost in terms of scaling or attracting larger numbers, it is a cost they are prepared to pay.

In their opening to others, the communications of these groups engage in what may be seen as new learning, in the sense of seeking to produce behavioural changes. ${ }^{14}$ In this manner, their communications have a clear pedagogical function that contributes to the development of new forms of consciousness, using on the one hand experiences and affects and on the other texts and analyses that ground, explain and contextualize these experiences and affects. The 'about us' section of the Contra-Info blog and translation network offers the most succinct example of this combination: 'Rage and consciousness!' ${ }^{15}$ It is not a temporary alliance that they seek but deep and permanent changes in how the world is viewed and understood. Scaling therefore takes place through the conscious, purposeful and consistent dissemination of learning, including both practice-based and conceptual-theoretical.

It is clear from the above that the communications and political practices of these groups differ both from Laclau's populist hegemony but also from the notion of folk politics as criticised by Srnicek and Williams. Populist hegemony as discussed by Laclau (2007) looks to bind together unsatisfied demands into chains of equivalence, coalescing around symbols and slogans, subsequently capitalized upon by leaders who then construct 'the people' they are supposed to represent in their confrontation with the existing political order. However, the communicative and political strategies of the groups under study are explicitly against the notion of leadership and the construction of a united people. Their emphasis is on direct and localized action and or-

${ }^{13}$ In a significant gesture of opening and solidarity, the historical anarchist newspaper Apatris published an Arabic edition (both print and online), found here: https://issuu.com/apatrisinternational/docs/aparab1-webdraft

${ }^{14}$ Morgan et al. $(1986,170)$ cite a typical definition of learning as involving relatively permanent changes in behaviour or mental processes as a result of practice or experience.

${ }^{15}$ See https://en-contrainfo.espiv.net/2015/03/01/contra-info-translation-counterinformation-network-2010-2015/ 
ganizing, and instead of looking to unite the people they are more interested in pointing the fault lines that separate people across class and other divides. Instead of using communication to form equivalences and symbols to point to these equivalences, they use it on the one hand instrumentally to achieve immediate and pragmatic goals and on the other to reinforce their identity, and to instigate and disseminate new learning.

Does this make them part of folk politics? This kind of politics, according to Srnicek and Williams $(2015,12)$ refers to "a collective and historically constructed political common sense that has become out of joint with the actual mechanisms of power" and because of this, it holds the left back. Folk politics revolves around three kinds of immediacy: temporal, spatial and conceptual. Temporally, it is reactive, as it reacts to actions initiated by corporations and governments and prioritizes the voluntarist and spontaneous over the institutional. Spatially, it prioritizes the local and the small and emphasises direct action, while finally in terms of conceptual immediacy there is a preference of the everyday, the affective, the personal and the particular over the structural, the abstract and the universal. Srnicek and Williams are quick to point out that this is an abstraction that is not embodied by any single position; rather folk politics must be seen as instantiated in varying degrees in concrete political positions. The problem, argue Srnicek and Williams, is that while folk politics is a necessary condition for any political project, it is not sufficient because it cannot address the question of scaling and strategy and for this reason it cannot adequately deal with global capitalism and any postcapitalist political project. In Srnicek and Williams' view, we require a combination of strategic, structural and analytic thinking in politics with ways of doing politics that pay attention to expansion and scaling. For this to be accomplished the left has to develop a project that can become counter-hegemonic to neoliberal capitalism.

It is evident that the insistence on direct and localized action, on forms of leaderless horizontal organization, and a dislike of both populism and hegemony are central to the field of thought we encountered here, even if they are also critical of affect on its own. Does this mean that this political thought and action is ineffectual? A closer look reveals certain tensions in the argument put forward by Srnicek and Williams. Their view of folk politics as necessary but insufficient hinges on the question of scaling: it is only insufficient because it cannot scale. Only hegemony can scale, because it is universalist in its orientation and only populism can succeed because it seeks to create a common language and project in spite of the various particularities of all those forming 'the people'. Scaling and a universalist horizon gloss over particularities at least temporarily as differences and particularities can never be totally resolved or suppressed. But in the above analysis we saw that the political perspective of the anarchist, libertarian and autonomist groups approach the question of scale in a different manner: rather than scaling by glossing over or subsuming particularities, they are more concerned with the production of new forms of subjectivity based on the one hand on experience and on the other on learning. The various experiences are then linked or connected together in solidarity but without converging. From this point of view, the issue is not one of scaling into a hegemony that subsumes different and occasionally contradictory demands but one of long lasting change in political subjectivities that will emerge out of experiences, out of thinking and theorizing and out of collaboration and exchange. Not one therefore of a mass political project but a series of interconnected multiple socio-political projects linked but not becoming equivalent, while also confronting state and authority structures. For this line of thought, building commonalities and common spaces is not the preserve of populism 
but can be arrived at in a different method, and potentially with less contradictions and with more attention to difference.

\section{Conclusion}

The paper has examined the genealogy of left-wing movements in Greece, detailing the emergence and defeat of EAM/ELAS, the ideological stronghold of KKE, and the post-civil-war authoritarian political climate. Following the imposition of the right-wing military dictatorship (1967-1974), which intensified repression and political persecutions, we identified a certain political imaginary created by these dramatic events, an imaginary that is echoed in the discourses of many Greek leftist movements, including the 'early Pasok' and Syriza, as well as in the relatively small anarchist space. We have seen that the hegemonic left was firstly controlled by the KKE, then by $\mathrm{Pa}-$ sok, and finally by Syriza. Pasok, lost its populist character once it embraced economic liberalism, and more importantly, when it accepted the EU directed austerity policies as inevitable. Syriza, on the other hand, collapsed due to its unsuccessful attempts not only to break with the unpopular policies of the Troika, but also to mobilize European publics against neoliberalism; while it still mobilises populist rhetoric, words and deeds are totally disconnected.

In parallel, we traced the anarchist and self-organising collectives, paying attention to their communicative practices. We followed the evolution of the antagonistic movement, from small, marginal and repressed initiatives, countercultural trends and autonomist currents. Finally, we tracked the movement from its occasional irruptions to the more consolidated, stronger and more socialised movement that has emerged, revolving around the revolt of 2008, the squares of 2011 and following Syriza's simultaneous victory and defeat in 2015. Tracing the parallel history of those operating outside the left party hegemony and outside state control, we sought to identify and make sense of their communication strategies, contextualized within the social and political history of Greece.

Broadly conceived, the horizontal antagonistic activists run occupied social spaces, and have become involved in the solidarity and cooperative economy, including self-managed factories and shops, and in the solidarity clinics, food banks, and refugee support centres. Some activists are also involved in anti-statism, targeting its apparatus, especially the police, having also established connections with struggles taking place in other parts of the world. Communication is an integral part in all this, relying on a vibrant sphere of communal and individual blogs, social media pages, online radio broadcasts, websites and individual accounts. Using instrumental communication to get things done, using news and crosslinks but also translations to connect to others, and by developing their own accounts, explanations, and interpretations of classic and current texts, local and global events, they attempt to spread and socialise their ideas, creating a common space in order to develop a social movement in a lateral manner without compromises. These practices we see as part of a different political strategy that opposes hegemonic populism (the type of populism that is controlled by party bureaucracies and mechanisms of representation), but still revolves around the principles of socialism and social justice, direct democracy and political participation.

\section{References}

Bennett, W. Lance and Alexandra Segerberg. 2012. The Logic of Connective Action. Information, Communication \& Society 15 (5), 739-768. 
Bennett, W. Lance and Alexandra Segerberg. 2013. The Logic of Connective Action: Digital media and the Personalization of Contentious Politics. Cambridge: Cambridge University Press.

Costanza-Chock, Sasha, 2012. Mic Check! Media Cultures and the Occupy Movement. Social Movement Studies 11.3-4: 375-385.

Dean, Jodi. 2012. Occupy Wall Street: After the Anarchist Moment. Socialist Register 49.

Douzinas. Kostas. 2013. Philosophy and Resistance in the Crisis. Cambridge: Polity Press.

Filippidis, Christos. 2011. Spatial Legacies of December and the Right to the City. In Revolt and Crisis in Greece, edited by Antonis Vradis and Dimitris Dalakoglou, 59-76. Edinburgh: AK Press.

Foucault, Michel, 1977. Language Counter-Memory Practice: Selected Essays and Interviews. New York: Cornell University Press.

Fuchs, Christian. 2014. Occupy Media!: The Occupy Movement and Social Media in Crisis Capitalism. John Hunt Publishing.

Gerbaudo, Paolo, 2012. Tweets and the Streets: Social Media and Contemporary Activism. London: Pluto Press.

Gerbaudo, Paolo and Emiliano Treré, 2015. In Search of the 'We' of Social Media Activism: Introduction to the Special Issue on Social Media and Protest Identities. Information, Communication \& Society 18(8), 865-871.

Hallin, Daniel C., and Stylianos Papathanassopoulos. 2002. Political Clientelism and the Media: Southern Europe and Latin America in Comparative Perspective. Media, Culture \& Society 24 (2): 175-195.

Kaplanis, Yiannis. 2011. An Economy that Excludes the Many and an "Accidental" Revolt. In Revolt and Crisis in Greece, edited by Antonis Vradis and Dimitris Dalakoglou, 207-214. Edinburgh: AK Press.

Karyotis, Georgios and Wolfgang Rudig, 2015. Protest Participation, Electoral Choices and Public Attitudes towards Austerity in Greece. In The Politics of Extreme Austerity, edited by Roman Gerodimos and Georgios Karyotis, 123-141. Hampshire: MacMillan.

Kavada, Anastasia. 2015. Creating the Collective: Social Media, the Occupy Movement and its Constitution as a Collective Actor. Information, Communication \& Society 18 (8): $872-$ 886.

Kornetis, Kostis. 2013. Children of the Dictatorship. Oxford: Bergham Books.

Kouki, Hara. 2011. Short Voyage to the Land of Ourselves. In Revolt and Crisis in Greece, edited by Antonis Vradis and Dimitris Dalakoglou, 167-180. Edinburgh: AK Press.

Laclau, Ernesto. 2007. On Populist Reason. London: Verso.

Mazower, Mark. 2001. Inside Hitler's Greece. Yale: Yale University Press.

Metropolitan Sirens. 2011. The (Revolt) Medium is the Message: Counter-Information and the 2008 Revolt. In Revolt and Crisis in Greece, edited by Antonis Vradis and Dimitris Dalakoglou,133-150. Edinburgh: AK Press.

Morgan, Clifford Thomas, Richard Austin King, John R. Weisz, and John Schopler. 1986. Introduction to Psychology. New York: McGraw-Hill.

Ovenden, Kevin. 2015. Syriza: Inside the Labyrinth. London: Pluto.

Papathanassopoulos, Stelios. 2001. Media Commercialization and Journalism in Greece. European Journal of Communication 16(4), 505-521.

Prentoulis, Marina, and Lars Thomassen. 2014. Autonomy and Hegemony in the Squares: The 2011 Protests in Greece and Spain. In Radical Democracy and Collective Movements Today, edited by Alexandros Kioupkiolis and Giorgios Katsambekis, 213-234. Surrey: Ashgate.

Rakopoulos, Theodoros. 2014. Resonance of Solidarity: Meanings of a Local Concept in Anti-Austerity Greece. Journal of Modern Greek Studies 32(2): 313-337.

Re, Mila. 2015. The Indignants of Mordor.

Sheehan, Helena. 2017. The Syriza Wave: Surging and Crashing with the Greek Left. New York: Monthly Review Press. 
Shiner, Larry. 1982. Reading Foucault: Anti-Method and the Genealogy of PowerKnowledge. History and Theory 21 (3): 382-398.

Srnicek, Nick, and Alex Williams. 2015. Inventing the Future: Folk Politics and the Left. London: Verso.

Stavrakakis Yiannis, and Giorgos Katsambekis, 2014. Left-wing Populism in the European Periphery: The Case of Syriza. Journal of Political Ideologies 19 (2): 119-142.

Stavrakakis, Yiannis. 2005. Religion and Populism in Contemporary Greece. In Populism and the mirror of democracy, edited by Francisco Panizza, 224-249. London: Hurst and Company.

Theocharis, Yannis. 2015. Every Crisis is a Digital Opportunity: The Aganaktismenoi Movement's Use of Social Media and the Emergence of Networked Solidarity in Greece. In The Routledge Companion to Social Media and Politics, edited by Axel Bruns, Gunn Enli, Eli Skogerbo, Anders Olof Larsson and Christian Christensen, 184-197. New York: Routledge.

Theodosiadis, Michael, 2013. Lessons from 6 December, 2008. Open Democracy [online]. Accessed October 10, 2016. https://www.opendemocracy.net/can-europe-makeit/michael-theodosiadis/lessons-from-6-december-2008

Theodosiadis, Michael. 2015. The Greek December Revolt and its Current Relevance. The Institute of Anarchist Studies. Accessed March 10, 2016.

http://anarchiststudies.org/2015/04/08/the-greek-december-revolt-and-its-currentrelevance-by-michail-theodosiadis/

Trocchi, Alex. 2011. For the Insurrection to Succeed, We Must First Destroy Ourselves. In Revolt and Crisis in Greece, edited by Antonis Vradis and Dimitris Dalakoglou, 299-328. Edinburgh: AK Press.

Voglis, Polymeris. 2000. Between Nation and Self-Negation: Political Prisoners in Greece 1945-1950. In After the War Was Over: Reconstructing the Family, Nation and State in Greece, 1943-1960, edited by Mark Mazower, 73-90. New Jersey: Princeton University Press.

Vradis, Antonis, and Dimitris Dalakoglou (eds.), 2011. Revolt and Crisis in Greece. Edinburgh: AK Press.

In Greek:

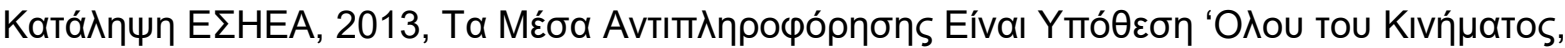
[Occupy ESIEA (Journalists' Union) Counter-information Media are an Issue for the Whole Movement] April 26. Accessed May 10, 2016: http://katalipsiesiea.blogspot.ie/2013/04/blog-post 1607.html


Пв́тро $\triangle$. Kapaßákо [Kordatos, Georgios, 1956. History of the Greek Labour Movement. 2nd ed. Athens: Petros Karavakos].

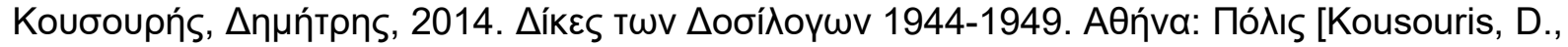
2014. The Trials of Collaborationists 1944-1494. Athens: Polis].

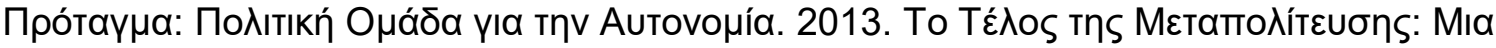
Хартоүра́

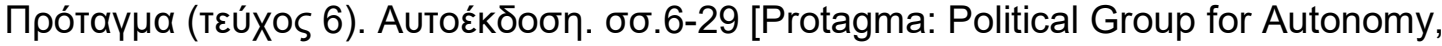
2013. The end of the Metapolitefsi: A Mapping of Convergence Between the Extreme Right and Liberalism. Protagma magazine (issue 6). Greece: Self-published. pp.6-29]

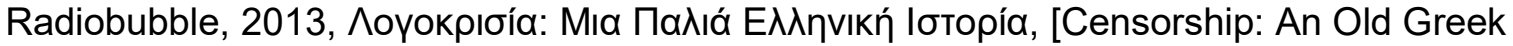
Story] June 16. Accessed May 10, 2016 http://news.radiobubble.gr/2013/06/blogpost_16.html 


\section{About the Authors}

\section{Eugenia Siapera}

Eugenia is a Senior Lecturer at the School of Communications in Dublin City University. She is the editor of Radical Democracy and the Internet (with Lincoln Dahlberg, Palgrave, 2007) and the Handbook of Global Online Journalism (with Andreas Veglis, Wiley, 2012), and the author of Global Media and Cultural Diversity (Wiley, 2010) and Understanding New Media (2012, second edition 2017).

Michael Theodosiadis

Michael is a $\mathrm{PhD}$ Candidate and academic mentor in Goldsmiths, University of London. He has also studied Social and Political Theory in Birkbeck, University of London (MSc). He is an academic mentor in Goldsmiths and his research field is focused on populism, direct democracy, civic republicanism, civic humanism, modern Greek politics and American Literature. 